\title{
Milk Culture Results in a Large Norwegian Survey-Effects of Season, Parity, Days in Milk, Resistance, and Clustering
}

\author{
O. Østerås, ${ }^{*} \dagger^{1}$ L. Sølverød, ${ }^{*}$ and 0. Reksen $\dagger$ \\ *Department of Norwegian Cattle Health Services, TINE Norwegian Dairies BA, Ås, Norway \\ †Department of Production Animal Clinical Sciences, Norwegian School of Veterinary Science, Oslo, Norway
}

\begin{abstract}
A nationwide random computerized assignment survey that included 3,538 sets of 4 quarter milk samples from 2,834 dairy cows was conducted during 2000. Every fifth cow from every 50th herd was randomly selected for sampling and culture during each quarter of the year. Milk culture results of pathogens known to be related to mastitis were recorded regardless of whether mastitis had been indicated by any inflammatory measure or not. Farmers were blinded to all test results to minimize any potential interventions that might be prompted by the results. The most prevalent isolate was Staphylococcus aureus, which was identified in $8.2 \%$ of the quarter milk samples. More than 15 colony-forming units $/ 0.01 \mathrm{~mL}$ of Staph. aureus were found in $4.3 \%$ of the quarter milk samples, whereas $3.5 \%$ had only 1 to 3 colony-forming units/0.01 mL. Streptococcus dysgalactiae, coagulase-negative staphylococci (CNS), and Streptococcus uberis were isolated from 1.2, 3.3, and $0.4 \%$ of quarter milk samples, respectively. No isolates were found in $76.6 \%$ of the quarter milk samples tested. Among individual cows, $22.2 \%$ had an isolate of Staph. aureus in $\geq 1$ quarter. Only Strep. dysgalactiae exhibited a higher prevalence with increased parity. Prevalence of Staph. aureus decreased throughout days in milk, but prevalence of Strep. dysgalactiae increased. There was a strong seasonal effect; the highest prevalence of Strep. dysgalactiae and CNS was observed during April and May (late indoor season), and the highest prevalence of Staph. aureus and Strep. uberis was observed during June and July (the outdoor season). A substantial within-cow clustering effect was found for Strep. dysgalactiae, Staph. aureus, and CNS. Additionally, a within-herd effect was found for Strep. uberis, penicillin-resistant Staph. aureus, total Staph. aureus, and CNS. No within-county cluster effect was found. Lastly, both Staph. aureus and CNS exhibited a surprisingly high seasonal effect regarding the prevalence of resis-
\end{abstract}

Received April 5, 2005.

Accepted October 25, 2005.

${ }^{1}$ Corresponding author: olav.osteras@tine.no tance to penicillin G. Penicillin resistance of Staph. aureus was likely due to higher prevalence of Staph. aureus as a whole, but for CNS, there was also an additional increase caused by a higher proportional rate of penicillin resistance during the late indoor season.

Key words: parity, days in milk, season, penicillin resistance

\section{INTRODUCTION}

Norway's organized mastitis control program, which was established in 1982, has been an integral part of the Norwegian Cattle Health Services since 1995. The goal of the mastitis control program is to reduce the overall cost of udder health problems for the individual farm by pursuing a strategy that addresses current udder health problems. There are 2 main classes of mastitis. The first is clinical mastitis, which manifests signs observed from the animal or the milk. The other is subclinical mastitis, which produces no visible signs from the udder except when using diagnostic tools (International Dairy Federation, 1999). The distribution of mastitis pathogens may differ between clinical and subclinical mastitis, as clinical mastitis can be caused by pathogens that are present for a short duration and produce obvious clinical signs. Conversely, subclinical mastitis can be caused by pathogens that are present for longer periods of time and produce negligible clinical signs.

In recent years, the Norwegian dairy industry has experienced a marked decrease in bulk milk SCC (BMSCC) from 173,000 to $113,000 / \mathrm{mL}$ (geometric mean) from 1988 to 2000 . In contrast, the incidence of clinical cases has increased from 0.30 primary cases per cow in 1998 to 0.35 primary cases per cow in 1994; then, a decrease was observed until 2000 when number of primary cases per cow fell to 0.23 (Norwegian Cattle Health Services, 2004). A minimal relationship was reported between clinical cases at herd level and BMSCC (Valde et al., 2005). The reason for this could be that low BMSCC levels can be achieved through targeted therapy of cows with high SCC, withholding high SCC milk either at quarter or cow level from delivery, or both. Usually routine samples sent to the mastitis labo- 
ratories for microbiological culture are from selected cows with a high cow milk SCC and from herds with high BMSCC. Such samples may not reflect the true prevalence of pathogens in the dairy population.

Subclinical mastitis is a common reservoir of infectious pathogens (Yancey et al., 1991). Information about the distribution and antibiotic susceptibility pattern of mastitis pathogens in milk samples in the dairy population is important for strategic decision making and optimal planning of mastitis control programs. A recently reported national surveillance study in Finland (Pitkälä et al., 2004) demonstrated a major shift in the pathogens identified from the predominance of Staphylococcus aureus in 1995 to CNS in 2001. Few countries have conducted national surveillance studies, and to date, no such study has been carried out on the Norwegian dairy population. Information concerning the prevalence of mastitis pathogens in relation to season, DIM, parity, and possible clustering effects within cow, herd, or county would be important in terms of developing a strategy for mastitis control, therapy, and design of therapeutic trials.

The goals of this epidemiological study were to conduct a random survey of udder quarters and cows in Norway to describe the point prevalence and distribution of possible subclinical mastitis pathogens, to describe the antimicrobial resistance patterns of these pathogens, and to describe possible associations between the presence of a pathogen and factors such as season, DIM, parity, and any cluster effects within cow, herd, or county.

\section{MATERIALS AND METHODS}

\section{Sampling}

All Norwegian dairy herds $(\mathrm{n}=20,858)$ taking part in the Norwegian Dairy Herd Recording System (NDHRS) as of December 31, 1998 were eligible for inclusion in the survey. This consisted of $89.2 \%$ of all dairy herds in Norway. A list of these herds was sorted according to identification number, and after the first herd was determined by assigning a random starting number between 1 and 49, every 50th herd was selected to join the survey. Thus, a total of 417 Norwegian dairy herds were included at the start of the survey. The survey started on January 1, 2000, and ended on January $1,2001$.

A complete list was compiled including every cow within the selected herds that had $\geq 1$ calving. These cows were sorted according to their unique identification number, and after the first cow was determined by assigning a random starting number from 1 to 4 , every fifth cow was selected for sampling. The lists of cows to be sampled were compiled in January, March,
June, and September. These lists were sent to the dairy advisors, who collected the milk samples and shipped them by priority mail to the Dairy Association Mastitis Laboratory in Molde, Norway. Samples from each quarter from all selected cows were sampled once during the following $3 \mathrm{mo}$. The within-herd selection of cows was designed so that each cow would have an even chance of being selected within each 3-mo sampling period. If a cow selected had been culled at the time of sampling, it was replaced with the most recent first parity cow entering that dairy herd. The number of cows selected in each 3 -mo period varied from 1,147 to 1,179 .

\section{Inclusions and Exclusions}

All together, 67 of the 417 herds were excluded before or during the study. Fifteen (3.6\%) of these 417 herds had discontinued their milk production during 1999, and 36 of the remaining 402 herds (9.0\%) stopped their milk production during 2000. An additional 16 herds were excluded from the study because 1) the farmer refused to cooperate (7 of 16), 2) farmers combined their herds with other farmers to form cooperative farms (3 of 16), 3) farmers terminated their membership in the animal recording scheme (3 of 16), and 4) other reasons (3 of 16). Therefore, 350 herds remained in the study through completion.

\section{Sample Collection}

The sampling and mailing procedures routinely used by the NDHRS were followed. The samples were usually drawn between milkings during normal working hours for the dairy advisors. Envelopes for mailing quarter milk samples were distributed to the dairy advisors. Each envelope contained a box with 4 sterile 10$\mathrm{mL}$ plastic tubes and a standard form for identification of farm and cow identity. The tubes were numbered according to the position of the quarter. Milk samples were drawn according to the Norwegian standard procedure. Teat ends were first well cleaned and dried. Then, 10 to $15 \mathrm{~mL}$ of milk was drawn and discarded, and the teat ends were scrubbed with a cotton or paper towel moistened with $70 \%$ ethanol; one towel was used for each teat. Good hygiene and dry hands during sampling were emphasized. The sample tube was filled $1 / 2$ to $3 / 4$ by 1 milking grasp. Samples were cooled in a refrigerator as soon as possible, at least within a few hours, after sampling and kept cooled until sent by mail as fast as possible to the mastitis laboratory. Samples drawn at the end of the week were kept cool by the sampler and were sent by mail to the laboratory on Monday. Samples arriving at the laboratory on Saturday were cooled at 
the laboratory until processing on Monday, thus avoiding an uncontrolled cooling chain for $>24 \mathrm{~h}$.

\section{Analyses of Milk Samples}

The samples were analyzed for bacterial growth from $0.01 \mathrm{~mL}$ of milk spread on blood agar plate (Blood Agar Base, Oxoid Ltd, Basingstoke, UK) mixed with 5\% washed bovine erythrocytes. The examination of bacterial growth and diagnostics followed the official Norwegian procedure of the National Veterinary Institute (1993) and was in agreement with the recommendations of the International Dairy Federation (1981). The plates were sectioned into 4 quadrants and incubated for 18 to $24 \mathrm{~h}$ at $37 \pm 1^{\circ} \mathrm{C}$. The samples were judged as contaminated if there was rich growth of $>2$ different types of colonies. If $>2$ quadrants were classified as contaminated, the advisors were asked to take new samples from the same cow as soon as possible. Typical colonies for Staphylococcus spp. that produced a typical $\beta$-hemotoxic zone were recorded as Staph. aureus. The combined growth of Staph. aureus and Streptococcus dysgalactiae was classified separately (code 70). Other colonies of Staphylococcus spp. were classified as coagulase positive or negative using Prolex Staph Latex Kit (Pro-Lab Diagnostics, Toronto, ON, Canada). Coagulase-positive Staphylococcus spp. were classified as Staph. aureus, and Strep. dysgalactiae were identified by colony morphology, hemolysis, negative CAMP, and esculine reaction. Streptococcus uberis were identified by colony morphology, hemolysis, CAMP, esculine reaction, no growth on lactose or saccarose agar, and a positive inuline reaction. Other Streptococcus spp. were classified based on colony morphology, hemolytic properties, CAMP reaction, and fermentation of esculine, and they were grouped according to Lancefield's system group A, B, C, D, F, and G. Growth of 1 to $3 \mathrm{cfu}$ or 4 to $15 \mathrm{cfu}$ of Staph. aureus $/ 0.01 \mathrm{~mL}$ was classified separately according to the Norwegian standard. A level of $>4 \mathrm{cfu} / 0.01 \mathrm{~mL}$ of other major udder pathogens in pure culture was designated as positive. Bacteria isolates other than Staph. aureus, Strep. dysgalactiae, or group B or G Streptococcae were recorded as minor mastitis pathogens. In accordance to Nordic recommendations for mastitis analysis of quarter milk samples (Klastrup and Schmidt Madsen, 1974), minor pathogens (code $>14$ except 70 and 71 in Table 1 ) were recorded when identified in pure culture at $>40 \mathrm{cfu} / 0.01$ $\mathrm{mL}$ per quadrant of the agar plate. All quadrants with isolates of Staph. aureus, CNS, Strep. dysgalactiae, Strep. uberis, and coliforms were selected for examination for antibiotic resistance using 3 to 5 random cfu from the agar plate. Because of missing test results of 2 isolates from 1 cow for Staph. aureus and CNS, 1 isolate for coliforms, 8 isolates from 3 cows for Strep. uberis, and 20 isolates for Strep. dysgalactiae, the total material for complete resistance testing was 1,155 isolates of Staph. aureus, 460 isolates of CNS, 135 isolates of Strep. dysgalactiae, 43 isolates of Strep. uberis, and 41 isolates of coliforms. Susceptibility patterns of penicillin, streptomycin, and tetracycline were determined following the official Norwegian procedure (National Veterinary Institute, 1993), which is in accordance with the International Dairy Federation's procedures (1981), using the diffusion agar method on Müller Hinton agar (Difco, Sparks, MD) and Neo-Sensitabs (A.S. Rosco, Taastrup, Denmark). All isolated pathogens were frozen for future investigations on antibiotic resistance factors. The bacterial results were kept confidential until January 1, 2001, to prevent the biasing of the results by treatment or management routines that might be prompted by this information.

\section{Statistical Analyses}

Data were compiled using the SAS software (version 8.02; SAS Institute, Inc., Cary, NC). Both descriptive and multivariable statistical analyses were performed. Different multivariable models were constructed using Proc Genmod. Cow and herd were introduced as random variables when the data were analyzed at the quarter level. Herd and county were introduced as random variables when analyzing data at the cow level. The test day was transformed to the 2 variables sine (test day) and cosine (test day) by the following equations in accordance with the method used by Schukken et al. (1992) to model seasonal associations on BMSCC.

$$
\begin{array}{r}
\text { Sine }(\text { test day })=\sin [2 \times \pi \times(\text { test day/365) }] \\
\text { Cosine }(\text { test day })=\cos [2 \times \pi \times(\text { test day/365) }]
\end{array}
$$

The model for the microbiological result was as follows.

$$
\begin{gathered}
\text { Microbiological isolate }(0,1)= \\
\mathrm{a}+\beta_{1} \text { lactation number }(1,2,>2) \\
+\beta_{2} \text { sine (test day) }+\beta_{3} \text { cosine (test day) } \\
+\beta_{4} \mathrm{DIM}+\beta_{5} \text { age of sample }
\end{gathered}
$$

The parity was classified in parity 1,2 , or $>2$ as a class variable. Days in milk and age of sample were used as continuous variables. The variable time for samples to reach the laboratory was also tested in the model as a dichotomous variable classified as $<3$ or $>2$ d. The model was run with a binomial distribution. Significance was assessed by Type III and Wald $\chi^{2}$ tests. 
Table 1. Numbers and types of isolates reported from the laboratory for each quarter sample

\begin{tabular}{|c|c|c|c|c|c|c|}
\hline \multirow[b]{2}{*}{ Code } & \multirow[b]{2}{*}{ Type of isolate } & \multicolumn{4}{|c|}{ Quarter site $^{1}$} & \multirow[b]{2}{*}{ Total (\%) } \\
\hline & & $\mathrm{RF}$ & $\mathrm{LF}$ & $\mathrm{RR}$ & LR & \\
\hline . & Dry quarters or empty sample & 76 & 87 & 107 & 125 & $395(2.8)$ \\
\hline 0 & Mixed flora (overgrowth) & 246 & 246 & 252 & 228 & $972(6.9)$ \\
\hline 1 & $>15 \mathrm{cfu}$ of $\beta$-toxic Staphylococcus aureus & 149 & 143 & 141 & 169 & $602(4.3)$ \\
\hline 2 & 4 to $15 \mathrm{cfu}$ of $\beta$-toxic Staph. aureus & 11 & 12 & 13 & 16 & $52(0.4)$ \\
\hline 3 & 1 to $3 \mathrm{cfu}$ of $\beta$-toxic Staph. aureus & 128 & 116 & 125 & 124 & $493(3.5)$ \\
\hline 6 & Anhemotoxic Staph. aureus & 0 & 0 & 1 & 0 & $1(0.0)$ \\
\hline 7 & Arcanobacterium pyogenes & 0 & 1 & 0 & 0 & $1(0.0)$ \\
\hline 10 & Streptococcus agalactiae & 0 & 0 & 0 & 0 & $0(0.0)$ \\
\hline 12 & Streptococcus dysgalactiae & 36 & 26 & 45 & 48 & $155(1.1)$ \\
\hline 13 & Streptococcus Lancefield group G & 0 & 0 & 1 & 1 & $2(0.0)$ \\
\hline 15 & Streptococcus uberis & 9 & 10 & 17 & 15 & $51(0.4)$ \\
\hline 16 & $\alpha$-hemolytic streptococci & 7 & 6 & 3 & 6 & $22(0.2)$ \\
\hline 18 & Anhemolytic streptococci & 0 & 0 & 1 & 0 & $1(0.0)$ \\
\hline 19 & Enterococcus species & 1 & 0 & 0 & 0 & $1(0.0)$ \\
\hline 20 & Escherichia coli (anhemolytic) & 5 & 3 & 7 & 11 & $26(0.2)$ \\
\hline 23 & Other coliform bacteria & 5 & 2 & 3 & 6 & $16(0.1)$ \\
\hline 30 & CNS & 102 & 104 & 137 & 119 & $462(3.3)$ \\
\hline 31 & Corynebacterium species & 1 & 1 & 0 & 0 & $2(0.0)$ \\
\hline 34 & Bacillus species & 2 & 2 & 2 & 1 & $7(0.1)$ \\
\hline 44 & Yeasts & 0 & 2 & 1 & 0 & $3(0.0)$ \\
\hline 48 & No bacterial growth & 2,749 & 2,768 & 2,670 & 2,655 & $10,842(76.6)$ \\
\hline 52 & Enterobacter species & 0 & 0 & 0 & 1 & $1(0.0)$ \\
\hline 70 & Staph. aureus and Strep. dysgalactiae & 1 & 0 & 3 & 3 & $7(0.1)$ \\
\hline 71 & Staph. aureus and antibiotics & 1 & 0 & 0 & 1 & $2(0.0)$ \\
\hline 96 & Sour milk & 9 & 8 & 8 & 9 & $34(0.2)$ \\
\hline \multirow{3}{*}{99} & Growth inhibitor & 0 & 1 & 1 & 0 & $2(0.0)$ \\
\hline & Total & 3,538 & 3,538 & 3,538 & 3,538 & $14,152(100)$ \\
\hline & Total Staph. aureus ${ }^{2}$ & 290 & 271 & 283 & 313 & $1,157(8.2)$ \\
\hline
\end{tabular}

${ }^{1} \mathrm{RF}=$ Right front; $\mathrm{LF}=$ left front; $\mathrm{RR}=$ right rear; $\mathrm{LR}=$ left rear.

${ }^{2}$ Sum of codes 1, 2, 3, 6, 70, and 71 .

The fit of the models was assessed by evaluation of deviance and change in deviance. The random cluster effects within cow and herd in this study were estimated using the alternative logistic regression method (Carey et al., 1993); herd was the subject, and cow was a subcluster using this equation at the quarter level in the SAS software.

$$
\begin{gathered}
\text { Repeated subject }=\text { herd/logor }= \\
\text { nest1 } \text { subcluster }=\text { cow identification }
\end{gathered}
$$

At cow level, the cluster effect within county and herd was as follows.

$$
\begin{gathered}
\text { Repeated } \text { subject }=\text { county/logor }= \\
\text { nest } 1 \text { subcluster }=\text { herd ID }
\end{gathered}
$$

Separate models were made for each microbe species or class of species in the same way for individual cow level results. The cows were designated positive for a certain specific species when $\geq 1$ of the quarters was positive for that species. The nonsignificant variables were removed one by one using a backward elimination procedure until all had $P<0.10 . P<0.05$ was judged as significant. For sine (test day) or cosine (test day), both were forced into the model if either or both were at $P<0.10$.

\section{RESULTS}

\section{Herds}

The 350 herds with complete herd data for year 2000 had a mean herd size of 14.9 cows ranging from 4 to 104 with a median of 12.7 cows. Mean production was $6,079(\mathrm{SD}=927) \mathrm{kg}$ of milk/yr. Altogether, $97.5 \%$ of all cows were of the Norwegian Red Cattle breed, and an additional $1.7 \%$ were mixed breeds with Norwegian Red included. Feeding consisted mainly of grass silage covering $39.4 \%$ of the energy consumption, concentrate accounted for an additional $39.5 \%$, and $16.9 \%$ of the energy requirements were covered by pasture. Pasture season usually runs from May or June until September or October depending on latitude. Altogether, 7.1\% of the dairies used free-stall barns, and the rest used tiestall barns; $60.1 \%$ of all farmers kept the heifers in a tie-stall system from service until $3 \mathrm{wk}$ before calving. In mastitis control programs that are typical for Scandinavia, emphasis is placed on dry and clean bedding 
areas, well-constructed milking machines, good milking practices with good preparation, good let down, and proper handling of clusters, whereas routine teat dipping and dry cow therapy are rarely recommended.

\section{Drop Outs}

A total of 4,645 cows were originally selected for sampling of which 463 cows dropped out. Of these cows, 336 belonged to farmers ending their production, 63 to farmers unwilling to cooperate, and 23 to herds that were not members of the animal recording any longer. Nineteen cows were from herds moved together with other herds, and 22 dropped out for unknown reasons. Additionally, samples were missing from 220 selected cows because they were dried off at sampling time, and 424 cows had missing samples for unknown reasons. A total of 3,538 sets of udder quarter milk samples were analyzed from 2,834 individual dairy cows: 2207 once, 555 twice, 67 three times, and 5 four times. Of the 3,538 randomly selected cows, 783 were replacement cows that were included because the selected cow was culled at the time of sampling.

Parity and DIM. There was no information regarding parity for 37 of the sampled cows. The distribution of parities was $41.0 \%$ first parity, $26.9 \%$ second parity, $16.3 \%$ third parity, $8.6 \%$ fourth parity, $4.0 \%$ fifth parity, and $3.1 \% \geq 6$ parity. Twenty-five percent of the samples were taken before 73 DIM, 50\% were taken before 154 DIM, and $75 \%$ were taken before 234 DIM. The mean day of sampling was $162 \mathrm{~d}(\mathrm{SD}=119 \mathrm{~d})$ postcalving. Only $2.5 \%$ had a sampling day later than 372 DIM. These figures were truncated in later analyses to 372 $\mathrm{d}$ because of some extreme values.

Age of Sample. Forty percent of the samples arrived at the laboratory within $1 \mathrm{~d}$ after sampling, $72 \%$ arrived within $2 \mathrm{~d}$, and $83 \%$ arrived within $3 \mathrm{~d}$. The multivariable model found no significant effect caused by sample age on the microbiological results. The samples were analyzed at one laboratory and the final diagnoses were made by only 2 veterinarians; one of them had responsibility for $91.1 \%$ of the diagnostics.

\section{Key Microbiological Findings}

Information regarding microbiological diagnoses from 13,757 quarters was obtained. Dry quarters accounted for 317 samples, and empty tubes that had been broken or experienced other accidental events during transport accounted for 78 samples for which no information was obtainable. Table 1 presents the number of isolates from the quarter samples. No microbiological growth occurred in $76.6 \%$ of the quarters. The main microbiological findings were as follows: 1,157 (8.2\%)
Staph. aureus, 972 (6.9\%) were contaminated samples, $462(3.3 \%)$ coagulase-negative Staphylococci spp. (designated as CNS), 162 (1.2\%), Strep. dysgalactiae, 51 (0.4\%) Strep. uberis, and $26(0.2 \%)$ Escherichia coli.

Of the Staph. aureus isolates, $602(4.3 \%$ of all samples) had $>15 \mathrm{cfu} / \mathrm{mL}, 52(0.4 \%)$ showed moderate growth (4 to $15 \mathrm{cfu} / \mathrm{mL}$ ), and $493(3.5 \%)$ showed $<4 \mathrm{cfu} /$ $\mathrm{mL}$ after $24 \mathrm{~h}$ of incubation. There was no identification of Streptococcus agalactiae, Pasteurella spp., Listeria monocytogenes, or Bacillus cereus.

\section{Resistance}

Staphylococcus aureus $(\mathrm{n}=1,155)$ were penicillin $\mathrm{G}$ resistant (PGR) in $11.4 \%$, resistant for streptomycin in $4.8 \%$, and resistant to tetracycline in $0.7 \%$ of the isolates. The results for CNS ( $\mathrm{n}=460)$ were $36.1,19.9$, and $2.6 \%$ for PGR, streptomycin, and tetracycline resistance, respectively; for Strep. dysgalactiae $(\mathrm{n}=135)$, the corresponding figures were 0.0, 7.4, and 1.5\%. For Strep. uberis $(\mathrm{n}=43), \mathrm{PGR}$ was found in $11.6 \%$ of the samples, $33.3 \%$ were resistant to streptomycin, and $4.8 \%$ were resistant to tetracycline, and for $E$. coli and other coliforms $(\mathrm{n}=41)$ resistance was $100.0,29.3$, and $14.6 \%$, respectively. For Staph. aureus, only 8 isolates $(0.7 \%)$ were resistant or partially resistant for both penicillin G and streptomycin. Similarly, for Strep. uberis, 2 isolates $(5.7 \%)$ had resistance to both antibiotics, and for CNS, 47 isolates (10.2\%) had resistance to both antibiotics. Table 2 shows the number of udder quarters and cows with PGR isolates of Staph. aureus or CNS for each quartile of the year. A higher number of resistant isolates were identified during the period from April to June, especially for CNS. This trend was extended into July to September for Staph. aureus.

The overall prevalence of udder sample sets (cow level) with any isolate of Staph. aureus was $22.2 \%$, for Strep. dysgalactiae was $3.9 \%$, for CNS was $10.3 \%$, and for Strep. uberis was $1.0 \%$. Cows with PGR Staph. aureus included $2.8 \%$, whereas PGR CNS was identified in $3.9 \%$ of cows. The number of quarters with isolates of the same microorganism at the cow level is presented in Table 3.

\section{Seasonal Association}

The observed prevalence of isolation of Staph. aureus over the 12-mo investigation period is illustrated in Figure 1. The highest prevalence for Staph. aureus was found from May to July, for CNS was found from April to July, for Strep. dysgalactiae was found from April to June, for Strep. uberis was found from May to July (Table 2; Figure 2), and for other Streptococcus was found from January and April (not illustrated). The 
Table 2. Number of quarters and cows with findings of penicillin G resistant (PGR) Staphylococcus aureus or coagulase-negative staphylococci (CNS) in each quarter of the year. Prevalence ${ }^{1}(\%)$ of all samples is presented in parentheses

\begin{tabular}{|c|c|c|c|c|c|c|}
\hline \multirow{3}{*}{$\begin{array}{l}\text { Annual } \\
\text { quarter } \\
\text { indicated } \\
\text { by months }\end{array}$} & \multirow{2}{*}{\multicolumn{3}{|c|}{ At quarter sample level }} & \multicolumn{3}{|c|}{ At cow level ${ }^{2}$} \\
\hline & & & & \multirow[b]{2}{*}{$\begin{array}{l}\text { Staph. } \\
\text { aureus }\end{array}$} & \multirow[b]{2}{*}{$\mathrm{CNS}$} & \multirow{2}{*}{$\begin{array}{l}\text { Total number } \\
\text { of quarter-set } \\
\text { samples at } \\
\text { cow level }\end{array}$} \\
\hline & $\begin{array}{l}\text { Staph. } \\
\text { aureus }\end{array}$ & CNS & $\begin{array}{l}\text { Total } \\
\text { number }\end{array}$ & & & \\
\hline Jan-Mar & $27(0.82)$ & $31(0.94)$ & 3,305 & $19(2.15)$ & $27(3.05)$ & 884 \\
\hline Apr-Jun & $39(1.25)$ & $94(2.81)$ & 3,113 & $31(3.48)$ & $76(8.54)$ & 890 \\
\hline Jul-Sep & $39(1.43)$ & $88(0.58)$ & 2,725 & $28(3.59)$ & $27(3.46)$ & 781 \\
\hline Oct-Dec & $27(0.74)$ & $38(0.21)$ & 3,642 & $20(2.03)$ & $9(0.92)$ & 983 \\
\hline Total & $132(1.03)$ & $251(1.19)$ & 12,785 & $98(2.77)$ & $139(3.93)$ & 3,538 \\
\hline
\end{tabular}

${ }^{1}$ Prevalence is defined as the number of PGR-positive isolates divided by the total number of quarters or quarter-set samples at the cow level within the same 3 mo of the year, multiplied by 100 .

${ }^{2}$ Total of 3,538 quarter sets from 2,834 randomly selected individual cows sampled $\geq 1$ time. One positive quarter sample from at least 1 of 4 quarters was defined as positive at the cow level.

${ }^{3}$ Total number of quarters, except 395 dry quarters and 972 quarters with overgrowth.

association with season was independent of the classification according to number of cfu of Staph. aureus that were identified in a sample.

\section{Association with DIM}

Table 4 shows the prevalence of different bacterial isolates when the lactation stage was divided in 4 equal lengths. There is a decrease in the prevalence of Staph. aureus throughout lactation and an increase of Strep. dysgalactiae. Table 5 shows the prevalence of Staph. aureus according to sampling time split on parity and lactation stage combined. Staphylococcus aureus was most prevalent in the early stage of lactation in first lactation cows and lowest in second lactation cows. First and second parity cows had a decrease in the observed prevalence of Staph. aureus throughout lactations.

\section{Multivariable Models with Cluster Effects Included}

All models had a significant fit assessed by change in deviance; the larger the change, the better. The models with bacteria isolates at the quarter level (Table 6) had better fit than the models at the cow level (Table 7). In general, models with Staph. aureus and CNS had the best fit according to change in deviance, and those with Strep. uberis did not have as good a fit. However, the overall best fit was found for the model with CNS at the cow level (Table 7) and for the model with PGR CNS for cows exclusively with positive isolates of CNS (Table 8).

Staphylococcus aureus. The model for Staph. aureus isolates in milk at the quarter level identified a significant association of test day (season) and DIM with the risk of Staph. aureus isolation (Table 6). The association of parity with isolation of Staph. aureus was close to significant for milk at the quarter level (Table 6), but was not significant at the individual cow level (Table 7). The cluster effect for Staph. aureus was greatest within cow, yielding an estimate of 1.58 (1.41 to $1.75)$ that corresponds to an odds ratio $(\mathbf{O R})$ of $e^{1.58}$ or $\mathrm{OR}=4.9$ (4.1 to 5.8). The within-herd cluster effect corresponds to an OR of 1.7 (1.4 to 2.0). Figure 2 shows

Table 3. The number of 4-quarter sample sets at the cow level (percentage in parentheses) with total numbers of quarters on each cow with the same bacterial isolates

\begin{tabular}{|c|c|c|c|c|c|c|}
\hline \multirow[b]{2}{*}{ Microbe } & \multirow{2}{*}{$\begin{array}{l}\text { Cows } \\
{\left[\text { no. }\left(\%{ }^{1}\right)\right]}\end{array}$} & \multirow{2}{*}{$\begin{array}{l}\text { Isolates } \\
\text { per positive } \\
\text { cow (no.) }\end{array}$} & \multicolumn{4}{|c|}{$\begin{array}{l}\text { Quarters with the same classified isolates within } \\
\text { the same udder sample set [cow level; no. }\left(\%{ }^{2}\right) \text { ] }\end{array}$} \\
\hline & & & 1 & 2 & 3 & 4 \\
\hline Staphylococcus aureus & $786(22.2)$ & 1.47 & $540(68.7)$ & $147(18.2)$ & $73(9.3)$ & $26(3.3)$ \\
\hline $\mathrm{PGR}^{3}$ Staph. aureus & $98(2.8)$ & 1.65 & $80(81.6)$ & $7(7.1)$ & $6(6.1)$ & $5(5.1)$ \\
\hline Streptococcus dysgalactiae & 139 & 1.17 & $122(87.8)$ & $12(8.6)$ & $4(2.9)$ & $1(0.7)$ \\
\hline Streptococcus uberis & $36(1.0)$ & 1.42 & $26(72.2)$ & 7 (19.4) & $1(2.8)$ & $2(5.6)$ \\
\hline CNS & $364(10.3)$ & 1.27 & $285(78.3)$ & $63(17.3)$ & $13(3.6)$ & $3(0.8)$ \\
\hline PGR CNS & $139(3.9)$ & 1.19 & $115(82.7)$ & $21(15.1)$ & $3(2.2)$ & $0(0.0)$ \\
\hline
\end{tabular}

${ }^{1}$ Percentage of all 3,538 sample sets from the 2,834 individual cows sampled randomly with $\geq 1$ quarter with a positive isolate within the same quarter set.

${ }^{2}$ Percentage of sample sets with 1, 2, 3, or 4 equal isolates within each sample set of 4 quarters.

${ }^{3} \mathrm{PGR}=$ Penicillin G resistant. 


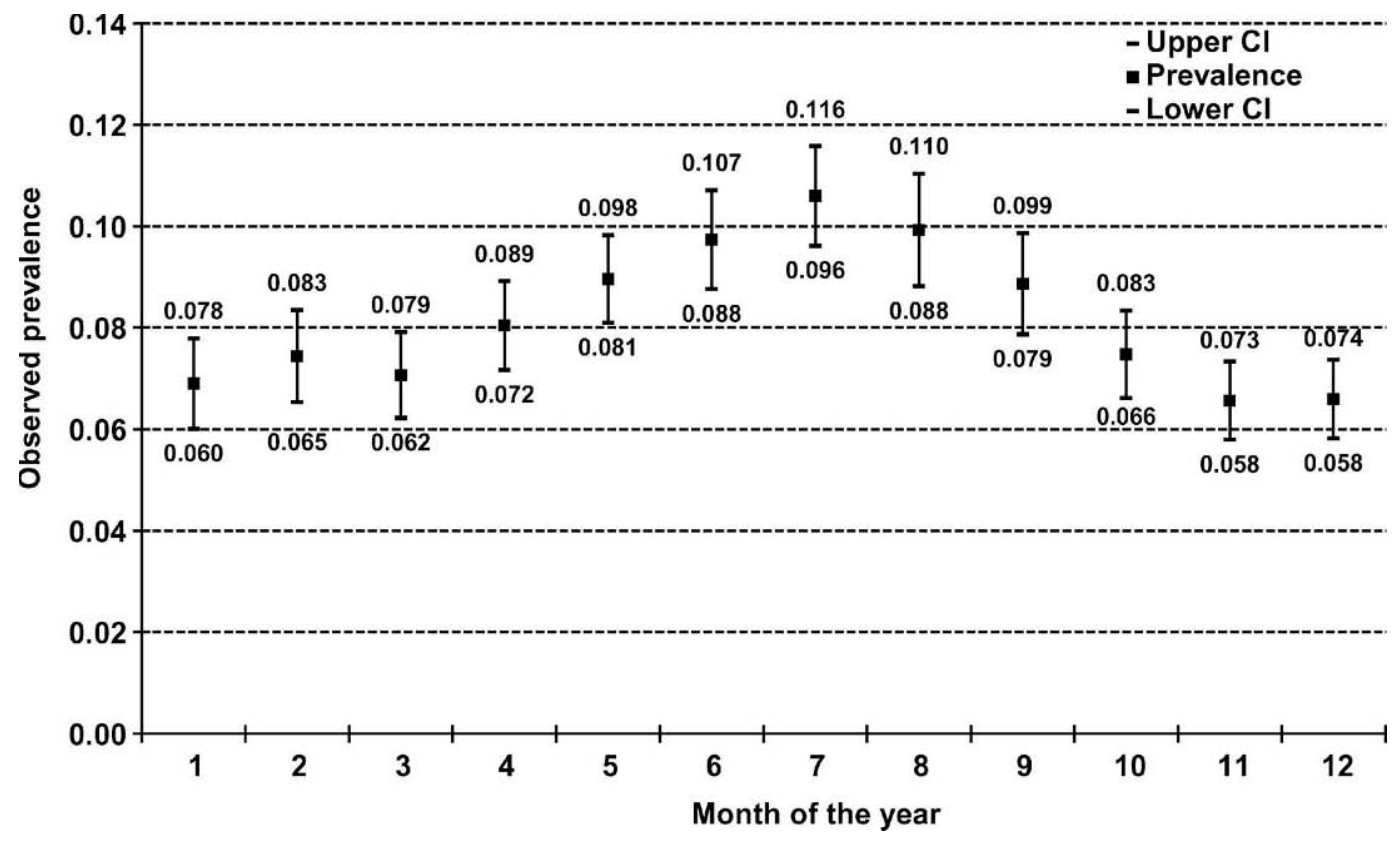

Figure 1. Rolling 3-mo means of observed prevalence (⿴) at the quarter level and upper and lower confidence intervals (CI; -) for isolated Staphylococcus aureus. Month 1 in rolling mean is mean of months 11, 12, and 1, etc.

the association of different pathogen isolates with season estimated from the multivariable models. There was no identified within-county cluster effect.

Penicillin G-Resistant Staphylococcus aureus. The multivariable models confirm the significant asso- ciation of season on PGR Staph. aureus both in the quarter level model (Table 6) and in the cow level model (Table 7). The same association was observed for PGR Staph. aureus and DIM. However, when cows exclusively with Staph. aureus were included in the multi-

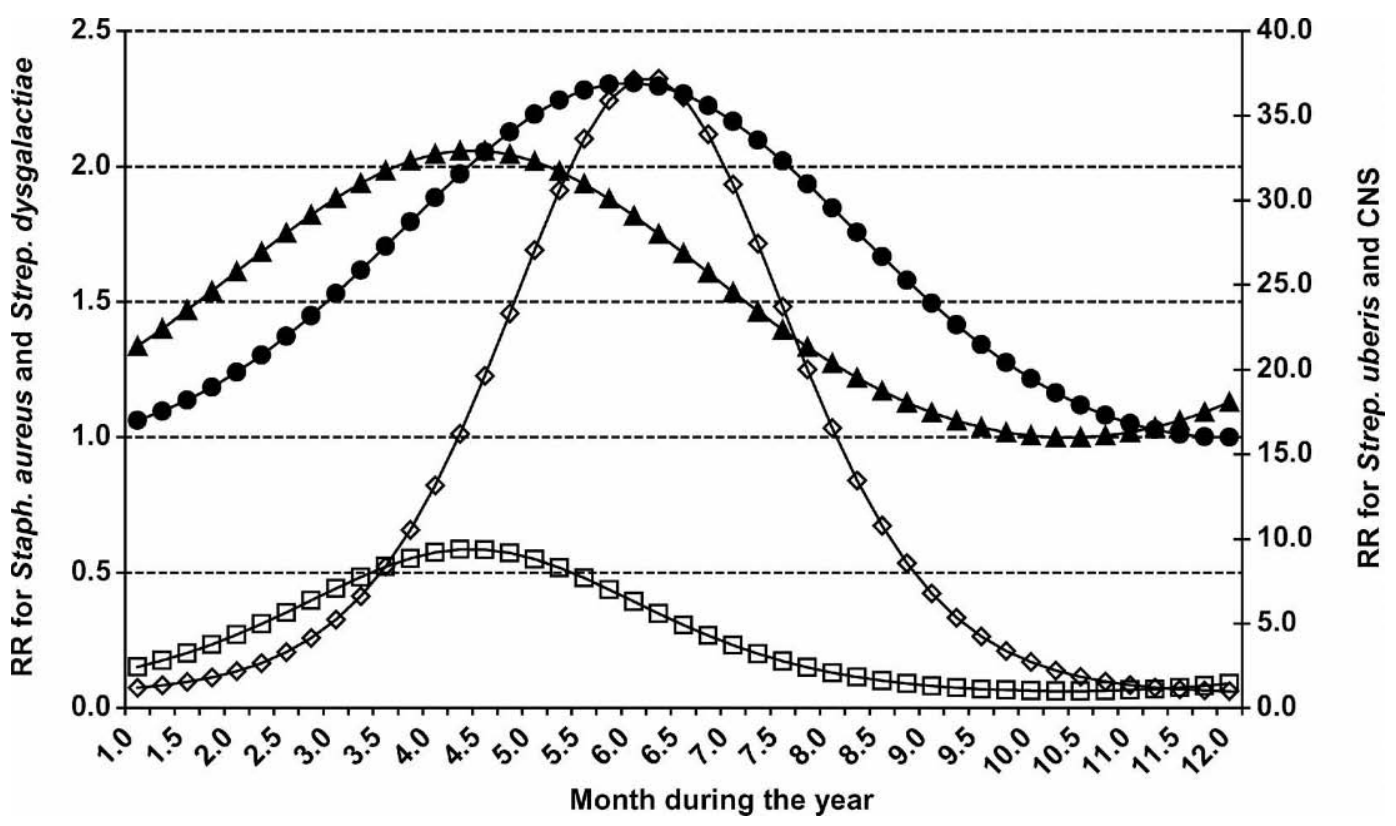

Figure 2. Modulated seasonal trends and relative risks (RR) at the quarter level for Staphylococcus aureus (৩) and Streptococcus dysgalactiae $(\boldsymbol{\Delta})$ on the left axis and coagulase-negative staphylococci (CNS; $\square$ ) and Streptococcus uberis $(\diamond)$ on the right axis. 
Table 4. Prevalence ${ }^{1}(\%)$ of specific bacteria isolated from quarters during each quarter of lactation

\begin{tabular}{|c|c|c|c|c|c|c|c|c|c|c|}
\hline $\begin{array}{l}\text { Stage in } \\
\text { lactation }\end{array}$ & $\begin{array}{l}\text { Staphylococcus } \\
\text { aureus }\end{array}$ & $\begin{array}{l}\text { Streptococcus } \\
\text { dysgalactiae }\end{array}$ & $\begin{array}{l}\text { Streptococcus } \\
\text { uberis }\end{array}$ & $\begin{array}{l}\text { Other } \\
\text { Streptococci }\end{array}$ & Coliforms & $\mathrm{CNS}$ & $\begin{array}{l}\text { No. of } \\
\text { isolates }\end{array}$ & $\begin{array}{l}\text { Mixed } \\
\text { flora }\end{array}$ & $\begin{array}{l}\text { Dry } \\
\text { quarters }\end{array}$ & $\begin{array}{l}\text { No. of } \\
\text { quarters }\end{array}$ \\
\hline$<75$ DIM & 10.0 & 0.95 & 0.34 & 0.28 & 0.22 & 3.07 & 74.6 & 7.49 & 2.60 & 3,580 \\
\hline 75 to 155 DIM & 8.7 & 1.06 & 0.26 & 0.06 & 0.43 & 3.00 & 77.1 & 6.31 & 2.97 & 3,500 \\
\hline$>234$ DIM & 6.5 & 1.50 & 0.48 & 0.20 & 0.40 & 3.98 & 77.0 & 7.13 & 2.57 & 3,464 \\
\hline Missing DIM & 8.3 & 0.64 & 0.64 & 0.64 & 0.00 & 2.56 & 71.2 & 14.10 & 1.92 & 156 \\
\hline Total & 8.2 & 1.14 & 0.36 & 0.18 & 0.30 & 3.26 & 76.6 & 6.87 & 2.79 & 14,152 \\
\hline
\end{tabular}

${ }^{1}$ Prevalence $=($ Number of positive quarters/total number of quarters within each stage of lactation $) \times 100$.

${ }^{2}$ Also included empty tubes.

variable model, no association was apparent for any of the covariates other than the random effect within herd (Table 8). There was a significant association between PGR Staph. aureus and parity for quarter level results $[\mathrm{OR}=1.9$ (1.1 to 3.4)]. This association was not significant for the cow level model (Table 7). There was no significant within-cow cluster effect for PGR Staph. aureus; however, a very strong within-herd cluster effect was observed [OR $=8.8$ (4.5 to 16.9)].

CNS. The model with CNS as a dependent variable confirmed a highly significant seasonal association both for the quarter level model (Table 6) and for the cow level model (Table 7). There was no association between CNS and DIM. There was a borderline significant association between isolation of CNS (Table 7) and parity $>2$ compared with parity 1 [OR $=1.3$ (1.0 to 1.8$)$ ]. There was a strong within-cow cluster effect [OR $=4.7$ (3.5 to 6.3)] and a corresponding significant within-herd cluster effect $[\mathrm{OR}=1.4$ (1.2 to 1.6)] for the udder quarter model. The model with only CNS included revealed a significant association between PGR resistance and both season and DIM (Table 8). However, parity or the within-herd cluster effect was not significantly associated with the likelihood of PGR in CNS.

Streptococcus dysgalactiae. The model with Strep. dysgalactiae illustrated a nonsignificant association both for season $(P=0.06$ and 0.16$)$ and DIM $(P=0.07)$ for the quarter level results (Table 6). This was shown to be significant in the model at cow level (Table 7). There was a strong association of isolates with Strep. dysgalactiae and parity: $\mathrm{OR}=3.0$ (1.9 to 4.8 ) comparing parity $>2$ with first parity and $\mathrm{OR}=1.9$ (1.1 to 3.0) comparing second parity with first parity cows. There was a highly significant within-cow clustering [OR = 10.2 (6.4 to 16.3)]. There was also a within-herd cluster effect in the cow model [OR $=1.6$ (1.0 to 2.5)].

Streptococcus uberis. The model with Strep. uberis illustrated an association with season both at the quarter and cow levels (Tables 6 and 7). There were no parity, DIM, or within-cow cluster associations identified. However, there was a significant within-herd cluster association [OR $=11.2$ (6.2 to 20.3)].

\section{DISCUSSION}

This survey was constructed to acquire important information regarding microbiological prevalence in quarter milk samples in Norway during 2000. As in all field studies, we expected some natural, unavoidable dropouts, such as farmers leaving the dairy business. This reflected the overall percentage of producers dropping out of production and selling their quota at that time. Bias caused by dropout may be associated with producers with low milk quality or high infection levels being lost to follow up. Farmers refusing to join the project constituted only $1.4 \%$ of the total, which indicates that the survey response rate was very high and should not have biased the results. Samples not taken for other reasons accounted for $9.1 \%$ of the samples. This was most common during the summer when the

Table 5. Number of quarters and prevalence ${ }^{1}(\%$; in parentheses) of identified Staphylococcus aureus according to DIM and parity number

\begin{tabular}{lrrrrrr}
\hline Parity & Missing DIM & \multicolumn{1}{c}{$<$ DIM } & 73 to 155 DIM & 154 to 234 DIM & $>234$ DIM & $\begin{array}{l}\text { Quarters } \\
\text { [no. }(\%)]\end{array}$ \\
\hline 1 & $16(0.0)$ & $1,224(11.4)$ & $1,432(8.5)$ & $1,476(8.3)$ & $1,596(6.2)$ & $5,744(8.4)$ \\
2 & $0(-)$ & $1,120(8.6)$ & $904(8.0)$ & $880(6.3)$ & $860(5.9)$ & $3,764(7.3)$ \\
3 & $0(-)$ & $624(10.5)$ & $624(8.3)$ & $536(5.6)$ & $504(7.7)$ & $2,288(8.0)$ \\
$>3$ & $0(-)$ & $608(9.9)$ & $536(10.6)$ & $560(9.1)$ & $504(7.3)$ & $2,208(9.3)$ \\
Missing parity & $140(9.3)$ & $4(0.0)$ & $4(0.0)$ & $3,452(7.5)$ & $0(-)$ & $148(8.8)$ \\
Total number & $156(8.3)$ & $3,580(10.0)$ & $3,500(8.7)$ & $3,464(6.5)$ & $14,152,(8.2)$ \\
\hline
\end{tabular}

${ }^{1}$ Prevalence $=($ Number of positive quarters with isolates of Staph. aureus/total number of quarters within each stage of lactation $) \times 100$. 
Coble 6. Estimated results from the multivariable models [Proc Genmod (SAS Institute, Inc., Cary, NC); with cluster effects] of quarters with Staphylococcus aureus, penicillin G-resistant (PGR) Staph. aureus, Streptococcus dysgalactiae, Streptococcus uberis, and CNS as the dependent variable. $\Delta=$ Change in deviance for full model vs. no covariates in the model; $\mathrm{CI}=$ confidence interval

\begin{tabular}{|c|c|c|c|c|c|c|c|c|c|c|}
\hline \multirow{2}{*}{$\begin{array}{l}\text { Fixed and } \\
\text { random } \\
\text { variables }\end{array}$} & \multicolumn{2}{|c|}{ Staph. aureus } & \multicolumn{2}{|c|}{ PGR Staph. aureus } & \multicolumn{2}{|c|}{ Strep. dysgalactiae } & \multicolumn{2}{|c|}{ Strep. uberis } & \multicolumn{2}{|c|}{ CNS } \\
\hline & $\beta$ or $\Delta$ & CI of $\beta$ & $\beta$ or $\Delta$ & CI of $\beta$ & $\beta$ or $\Delta$ & CI of $\beta$ & $\beta$ or $\Delta$ & CI of $\beta$ & $\beta$ or $\Delta$ & CI of $\beta$ \\
\hline$\Delta$ Model & 94.0 & & 35.7 & & 39.6 & & 44.4 & & 175.4 & \\
\hline Intercept & $-2.27 * * *$ & -2.46 to -2.09 & $-4.59 * * *$ & -5.18 to -4.00 & $-5.37 * * *$ & -5.88 to -4.86 & $-6.16^{* * * *}$ & -6.7 to -5.6 & $-3.71 * * *$ & -3.9 to -3.5 \\
\hline Parity 1 & $0.15^{1}$ & -0.04 to 0.34 & $0.11^{\mathrm{NS}}$ & -0.45 to 0.68 & 0 & & & & 0 & \\
\hline Parity $2^{2}$ & 0 & & 0 & & $0.78^{* *}$ & 0.28 to 1.28 & & & $0.20^{3}$ & -0.02 to 0.42 \\
\hline Parity $>2$ & $0.15^{4}$ & -0.04 to 0.34 & $0.65^{*}$ & 0.08 to 1.23 & $1.01^{* * * *}$ & 0.54 to 1.48 & & & & \\
\hline Sine (test day) & 0.010 & -0.10 to 0.11 & -0.036 & -0.42 to 0.35 & $0.23^{5}$ & -0.007 to 0.47 & -0.112 & -0.74 to 0.51 & $0.69 * * *$ & 0.54 to 0.85 \\
\hline Cosine (test day) & $-0.32 * * *$ & -0.46 to -0.18 & $-0.67 * *$ & -1.12 to -0.22 & $-0.20^{6}$ & -0.48 to 0.08 & $-1.58 * *$ & -2.5 to -0.66 & $-0.60 * * *$ & -0.82 to -0.37 \\
\hline DIM & $-0.0018^{* * *}$ & -0.0026 to -0.0010 & $-0.0030^{*}$ & -0.0055 to -0.0005 & $0.0017^{3}$ & -0.0002 to 0.0035 & & & & \\
\hline Within cow ${ }^{7}$ & $1.58^{* * *}$ & 1.41 to 1.75 & & & $2.32^{* * *}$ & 1.86 to 2.79 & & & $1.54^{* * * *}$ & 1.24 to 1.84 \\
\hline Between cows ${ }^{7}$ & $0.51 * * *$ & 0.33 to 0.70 & $2.17 * * *$ & 1.51 to 2.83 & $0.40 *$ & -0.0078 to 0.82 & $2.43^{* * *}$ & 1.84 to 3.01 & $0.33^{* * * *}$ & 0.16 to 0.50 \\
\hline
\end{tabular}

${ }^{1} P=0.13$

${ }^{2}$ For the model of CNS, parity $2=$ all parities $>1$.

${ }^{3} P=0.07$.

${ }^{4} P=0.12$

${ }^{5} P=0.06$.

${ }^{6} P=0.16$

${ }^{7}$ Random variable.

$* P<0.05$; ** $P<0.01$; *** $P<0.001$

Table 7. Estimated results from the multivariable models [Proc Genmod (SAS Institute, Inc., Cary, NC); with cluster effects] for cows with Staphylococcus aureus, penicillin G-resistant (PGR) Staph. aureus, Streptococcus dysgalactiae, Streptococcus uberis, and CNS as dependent variables. $\Delta=$ Change in deviance for full model vs. no covariates in the model; $\mathrm{CI}=$ confidence interval

\begin{tabular}{|c|c|c|c|c|c|c|c|c|c|c|}
\hline \multirow{2}{*}{$\begin{array}{l}\text { Fixed and } \\
\text { random } \\
\text { variables }\end{array}$} & \multicolumn{2}{|c|}{ Staph. aureus } & \multicolumn{2}{|c|}{ PGR Staph. aureus } & \multicolumn{2}{|c|}{ Strep. dysgalactiae } & \multicolumn{2}{|c|}{ Strep. uberis } & \multicolumn{2}{|c|}{ CNS } \\
\hline & $\beta$ or $\Delta$ & CI of $\beta$ & $\beta$ or $\Delta$ & CI of $\beta$ & $\beta$ or $\Delta$ & CI of $\beta$ & $\beta$ or $\Delta$ & CI of $\beta$ & $\beta$ or $\Delta$ & CI of $\beta$ \\
\hline$\Delta$ Model & 45.1 & & 11.0 & & 32.2 & & 13.3 & & 93.4 & \\
\hline $\begin{array}{l}\text { Intercept } \\
\text { Parity } 1\end{array}$ & $-0.85^{* * *}$ & -1.0 to -0.67 & $-3.29 * * *$ & -3.7 to -2.9 & $\begin{array}{l}-4.19 * * * \\
0\end{array}$ & -4.7 to -3.7 & $-4.8^{* * * *}$ & -5.3 to -4.3 & $\begin{array}{l}-2.4^{* * * *} \\
0\end{array}$ & -2.7 to -2.2 \\
\hline Parity 2 & & & & & $0.62 *$ & 0.12 to 1.11 & & & $0.20^{\mathrm{NS}}$ & -0.09 to 0.50 \\
\hline Parity $>2$ & & & & & $1.10 * * *$ & 0.63 to 1.57 & & & $0.29 *$ & 0.001 to 0.58 \\
\hline Sine (test day) & 0.07 & -0.05 to 0.19 & 0.15 & -0.19 to 0.49 & 0.05 & -0.23 to 0.32 & 0.04 & -0.44 to 0.51 & $0.59 * * *$ & 0.41 to 0.76 \\
\hline Cosine (test day) & $-0.26 * * *$ & -0.40 to -0.12 & $-0.49 * *$ & -0.85 to -0.12 & $-0.33^{*}$ & -0.64 to -0.02 & $-1.12^{* *}$ & -1.94 to -0.31 & $-0.62 * * *$ & -0.86 to -0.38 \\
\hline DIM & $-0.0026 * * *$ & -0.004 to -0.002 & $-0.0025^{*}$ & -0.005 to 0.00 & $0.0022^{*}$ & 0.0002 to 0.0041 & & & & \\
\hline Within herd ${ }^{1}$ & $0.46^{* * *}$ & 0.23 to 0.70 & $1.35^{* * *}$ & 0.63 to 2.06 & $0.47 *$ & 0.013 to 0.92 & $1.56^{* * *}$ & 0.79 to 2.34 & $0.39 * * *$ & 0.17 to 0.61 \\
\hline
\end{tabular}

${ }^{1}$ Random variable.

$* P<0.05$; ** $P<0.01$; *** $P<0.001$. 
Table 8. Estimated results from the multivariable models [Proc Genmod (SAS Institute, Inc., Cary, NC); with cluster effects] when only those cows with Staphylococcus aureus or CNS were included in the model and with penicillin G-resistant (PGR) Staph. aureus or PGR CNS, respectively, as the dependent variable ${ }^{1}$

\begin{tabular}{|c|c|c|c|c|}
\hline \multirow{2}{*}{$\begin{array}{l}\text { Fixed and } \\
\text { random } \\
\text { variables }\end{array}$} & \multicolumn{2}{|c|}{ PGR CNS } & \multicolumn{2}{|c|}{ PGR Staph. aureus } \\
\hline & $\beta$ or $\Delta$ & CI of $\beta$ & $\beta$ & CI of $\beta$ \\
\hline$\Delta$ Model & 25.2 & & & \\
\hline Intercept & $-1.47 * * *$ & -2.13 to -0.80 & $-2.06 * * *$ & -2.4 to -1.77 \\
\hline Parity 1 & 0 & & & \\
\hline Parity 2 & $0.57^{2}$ & -0.03 to 1.16 & & \\
\hline Parity $>2$ & $0.38^{\mathrm{NS}}$ & -0.17 to 0.92 & & \\
\hline Sine (test day) & 0.16 & -0.22 to 0.56 & & \\
\hline Cosine (test day) & $-0.58 * *$ & -0.94 to -0.22 & & \\
\hline DIM & $0.0036^{* *}$ & 0.0009 to 0.0062 & & \\
\hline Within herd $^{3}$ & $0.55^{4}$ & -0.09 to 1.19 & $1.37 * * *$ & 0.55 to 2.18 \\
\hline
\end{tabular}

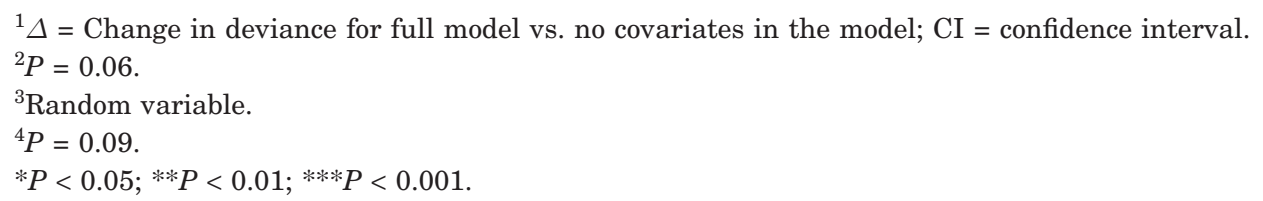

herd was out to pasture and people were on vacation or having other higher priority tasks. Overall, there was balanced representation in the total sample with regard to parity and DIM. The distribution of cows being sampled 2, 3, and 4 times was in accordance with the random sampling strategy in the study. The distribution of parities was very similar to the distribution within the whole population: $40.3 \%$ were sampled in first parity, $26.3 \%$ were sampled in second parity, $16.6 \%$ were sampled in third parity, and $9.2 \%$ were sampled in the fourth parity (TINE Norwegian Dairies, 2001). This also demonstrated that the substitution system for selected cows that had been culled worked well and resulted in the proper number of first parity cows in early lactation. This was also demonstrated by the even distribution of cows throughout DIM. The correct geographical and parity distributions, with only $1.4 \%$ unwanted dropouts, gave assurance that the material consisted of a true random sample from the Norwegian dairy cattle population within the recorded year.

All microbiological testing was done in one laboratory to ensure that the quality of diagnostics and methods was consistent. Most of the samples (83.2\%) arrived at the laboratory by the third day after sampling. All samples were kept cool by either the sampler or the laboratory, so that interruption of the cooling-chain should not have exceeded $24 \mathrm{~h}$. The statistical models were fit with age of sample as an independent variable, and age was found to have no significant contribution. To be sure that the association with season and pathogen isolates was not due to older samples having more growth during the summer, separate models were constructed for one data set with samples arriving at the laboratory in $<3 \mathrm{~d}$ and another data set with samples delivered to the laboratory at $>2 \mathrm{~d}$ after collection. The results of these models were not significantly different. Thus, the $16.8 \%$ of samples that were $>2 \mathrm{~d}$ in transport from the cow to the laboratory should not have biased our results. Some areas of the country might have longer transport distances and need all working days to draw all of the samples; their samples were included in the material to avoid geographical selection bias.

Nordic recommendations on mastitis diagnostics according to Klastrup and Schmidt Madsen (1974) with a limit of $40 \mathrm{cfu} / 0.01 \mathrm{~mL}$ was used as a cut-off for diagnosis of minor pathogens. This could cause a slight underestimation of these bacteria (code 15 to 44 and 52 in Table 1) in relation to the results presented by Pitkälä et al. (2004).

We tested antibiotic resistance by agar diffusion, which is the standard method for screening antibiotic resistance used in Norway. The study would have benefited from the use of the minimum inhibitory concentration method used by Pitkälä et al. (2004) in Finland, but the resources required were not available. The resistant strains were stored, and future studies should provide further insight into the type of bacterial resistance genes present. The diameter limits for resistance in the disc method used in this study were defined by values for minimum inhibitory concentration supplied by the manufacturer. Therefore, our results should be comparable with the results in the paper by Pitkälä et al. (2004) in Finland, although probably with less precision.

The predominant organisms isolated were Staph. aureus, CNS, and Strep. dysgalactiae. This result agrees with findings from earlier years from routine samples analyzed at the Norwegian Mastitis Laboratories. The only significant difference from the routine samples was the identification of a lower percentage of 
PGR Staph. aureus and CNS in the current study, which might be explained by more frequent, routine follow-up sampling in herds in which resistance has been revealed previously.

Very few surveillance studies have been done on a country-wide basis with the exception of one recent study from Finland (Pitkälä et al., 2004). The biggest difference between our study and theirs was a much lower fraction of CNS reported in Norway than in Finland: 3.3 vs. $16.6 \%$, respectively. The present study also found a high prevalence of Staph. aureus (8.2 vs. 3.4\%). However, we recorded all Staph. aureus, even if present with only $1 \mathrm{cfu} / 0.01 \mathrm{~mL}$ of milk. If we restrict our findings to $>15 \mathrm{cfu}$ of Staph. aureus, which would be more comparable with that reported from Finland, our calculated prevalence would be $4.3 \%$. The prevalence of Strep. uberis was low both in Norway and Finland studies $(0.4$ vs. $0.65 \%)$. This was in contrast to reports from the United States and the United Kingdom (Zadoks et al., 2004; Green et al., 2005). We did not identify any Corynebacterium bovis. This was expected, as C. bovis is very rarely isolated from cows in Norway. Pitkälä et al. (2004) reported a prevalence of C. bovis of $11.52 \%$ in Finland. Barkema et al. (1997) found a very high intraclass correlation for $C$. bovis, at the same magnitude as that of Streptococcus agalactiae, demonstrating a high degree of contagiousness. If $C$. bovis are contagious bacteria, as indicated by Barkema et al. (1997), this could support the hypotheses that $C$. bovis are still not very common nor spread in the Norwegian population yet. Another hypothesis is that the Norwegian cattle population's environment is not conducive to $C$. bovis infection. Our study reported that $76.6 \%$ of the quarters were classified as having no bacterial growth, whereas $62.4 \%$ were so classified in Finland. The proportion of PGR Staph. aureus in the current study was $11.4 \%$, but was $52.1 \%$ in Finland. We also found less resistance to tetracycline in our Staph. aureus isolates $(0.7 \%)$, whereas Finland's finding was $5.1 \%$. However, resistance to streptomycin was very similar (4.8\% in Norway and $4.1 \%$ in Finland).

There were also country-wide surveillance data collected in The Netherlands in 1973, 1975, 1980, and 1985 (Vecht et al., 1987). Those researchers reported a level of 6\% for Staph. aureus isolations from 1973 and $1975,3.7 \%$ from 1980, and 4\% from 1985. This was approximately the same result that we obtained, if a positive result is defined as a bacterial count of $>15 \mathrm{cfu}$ of Staph. aureus. Vecht et al. (1987) also report 1 to 1.5\% isolation rates for Strep. dysgalactiae and Strep. uberis, separately. Their result for Strep. dysgalactiae was similar to ours, but the rate of Strep. uberis in their study was much higher than that in the current report.
Busato et al. (2000) from Switzerland reported a Staph. aureus prevalence of $16.0 \%$ upon examination of quarters during 7 to 100 DIM and $7.4 \%$ during 101 to 305 DIM. Thus, Staph. aureus seems to be at a higher level in Switzerland during the first part of lactation than it is in Norway, but at the same level later in lactation.

Our survey suggests that the goal for the future will be to decrease the prevalence of Staph. aureus by testing different options such as teat dipping and dry cow therapy. Additionally, we need to look more closely at the reason for the high prevalence of Staph. aureus at calving, especially in first-parity cows or heifers. Preventive measures designed to reduce known risk factors, such as cross-suckling between calves, transmission by flies under pasture conditions (Owens et al., 1998; DeVliegher et al., 2004), and udder edema around calving (van Dorp et al., 1999; Waage et al., 2001), could be of importance. Further research needs to be done to quantify more exactly the importance of these factors under current conditions in Norway.

Number of Positive Quarters per Cow and Clustering. Table 3 shows that Staph. aureus was found in most quarters within the same cow if any Staph. aureus was isolated from a cow. This indicates that, for Staph. aureus, the transmission of bacteria is highest between quarters and within cows. The cluster effect within herds was largest for PGR Staph. aureus. This was linked to certain herds, indicating that resistance could be due to certain strains of bacteria existing within certain herds. This indicates that it could be important to avoid transferring such strains between herds. Such transmission in Norway has been previously described (Waage et al., 2002). County was introduced as a random effect to determine whether there was any geographical clustering of pathogens or PGR within the county as a consequence of animal trading between herds. Such clustering could also be generated because of different incidences of mastitis treatments between counties (Norwegian Cattle Health Services, 2004). However, no such clustering was identified. Streptococcus uberis also showed a large clustering effect within herd. This is in contrast to the findings of Barkema et al. (1997), who found very low within-herd correlation for Strep. uberis. However, our data set on Strep. uberis is very small, and care should be taken when interpreting our finding on this species. This indicates that either a specific strain was involved in the herds in this study or a specific environment within the herds contributed to the mechanism of infection. This hypothesis of specific strains is in accordance with the results of Zadoks et al. (2003). The model with only CNS- or Staph. aureus-positive cows (Table 8) showed a much larger cluster effect for PGR with Staph. aureus than 
with CNS. This indicates that there may be different mechanisms of transmission of resistance in these 2 bacteria. Resistance genes can be either incorporated into the bacterial genome or into plasmids (Yazdankhah et al., 2000). Staphylococcus aureus occurs more commonly in certain herds than does CNS, which hardly demonstrated any significant herd-level clustering effect. This is not in accordance with Barkema et al. (1997), who found very similar and moderate withinherd correlations of 0.05 and 0.07 for Staph. aureus and CNS, respectively. This could indicate that different strains of these pathogens exist in Norway than in The Netherlands. The Staphylococcus aureus strain differences among the Nordic countries have been described by Aarestrup et al. (1997).

Season. There was a very strong seasonal association of isolates for all bacteria as well as for resistance. The highest prevalence of Strep. dysgalactiae and CNS was found in the late indoor season between April and May in Norway, and the prevalence of Staph. aureus and Strep. uberis peaked during the period from June to July. The models with Strep. uberis or Strep. dysgalactiae as dependent variables did not have as good a fit as the models for Staph. aureus or CNS. This could have been due to the much lower positive numbers for Strep. uberis or Strep. dysgalactiae. The higher proportion of infected cows or quarters detected in the late indoor season could be linked either to reduced resistance caused by lower feed quality or to some climatic or hygienic conditions causing higher incidence or longer duration of infections. Feed quality may be linked to lower levels of vitamin $\mathrm{E}$ in stored feed. Vitamin $\mathrm{E}$ is known to have an impact on resistance to bacterial infections (Allison and Laven, 2000). The climatic or hygienic conditions should be similar during spring and winter, as cows are kept indoors during that time. However, during spring, there may be increased sunshine, which may increase the indoor temperature. Future research is needed to determine the exact reason for these differences. The peak in prevalence of Staph. aureus shown in Figure 2 might have been expanded to the right because of more persistent infections or higher new infection rates. Figure 2 also indicates that the peak of Staph. aureus prevalence is broader than the peak of CNS, nicely illustrated by the flat area from August to December for CNS. The average duration of infection is not significantly longer for Staph. aureus than for CNS (Lam et al., 1997), but some clone types of Staph. aureus cause more persistent infections (Haveri et al., 2005). Thus, the duration of infection could be linked more to clone type than to species, indicating that the late indoor season could also have an impact on Staph. aureus infections. Streptococcus uberis has a very distinct summertime peak. This result may be due to summer pasturing problems. Interestingly, Norway has a much lower Strep. uberis prevalence than other countries with much longer outdoor seasons. Norway has also fewer free-stall barns than other countries. Additionally, bedding material such as straw is infrequently used in many counties in Norway, and often a thin layer of sawdust on concrete or rubber mats is used as the only bedding material. Because streptococcal counts have been shown to be higher in chopped straw than in sawdust (Hogan et al., 1989), this could be one of the reasons why Strep. uberis is less frequently detected in Norway. The summer peak suggests that infections with Strep. uberis are more linked to climatic conditions, pasturing conditions, and the environment than are other bacteria in Norway. This corresponds very well to reports from New Zealand, where Strep. uberis contamination of paddocks and muddy races increased when wet conditions prevailed and when the cows' grazing density was higher (Lopez-Benavides et al., 2005). The Norwegian grazing season can be very wet, at least near the coastline, with muddy paddocks and races not uncommon during cold, wet weather.

The most surprising and new finding in this study was the huge seasonal association of the prevalence of PGR, both in Staph. aureus and CNS. As to PGR Staph. aureus, this is mainly due to higher prevalence of Staph. aureus during the summer as a whole, but for PGR CNS, there was also an additional increase caused by higher proportional rate of PGR CNS during the late indoor season. This is demonstrated by significant association of season and PGR CNS when the model is constructed only for quarters and cows positive for Staph. aureus and CNS, respectively. This finding potentially reflects different underlying mechanisms for development of occurrence of PGR in Staph. aureus compared with CNS. The reason for this finding is unknown; however, it was so characteristic that it will be important to investigate it in future studies. To our knowledge, there is, at present, no information in the bovine mastitis literature on the seasonal occurrence of PGR. However, such seasonality is for pneumococcal isolates causing acute otitis media in children (Hoberman et al., 2005). One hypothesis is that the transmission of resistance genes is dependent on temperature, the environment, or both, such that Norwegian summer conditions favor such transmission. This study at least illustrates large dynamics in the prevalence of PGR. According to mathematical models of infection dynamics (Kleinbaum et al., 1982), this means that incidence, duration, or both are also dynamic. The reasons for this dynamic behavior should be elucidated by future epidemiological and therapy studies that include PGR.

Association with DIM. The prevalence of both Staph. aureus and PGR Staph. aureus decreased 
throughout lactation. This could have been a result of farmers culling these cows. However, in this study, the microbiological findings were not shared with the farmers. The only way these cows could be identified was through higher SCC, according to the design of the survey and the blinding of the farmers. The prevalence of Strep. dysgalactiae increased during DIM, indicating an accumulation during lactation or a higher risk for new infection around the end of lactation.

\section{CONCLUSIONS}

This random survey from Norway in 2000 found that Staph. aureus, CNS, and Strep. dysgalactiae are the most prevalent bacteria isolated from quarter milk samples. There was a pronounced seasonal trend, and the highest prevalence was noted during late spring for Strep. dysgalactiae and CNS or during summer for Staph. aureus and Strep. uberis. Streptococcus dysgalactiae had a tendency to accumulate during lactation. The highest risk for the presence of Staph. aureus occurred just after calving. Streptococcus dysgalactiae showed the greatest within-cow clustering effect, but Staph. aureus and CNS displayed a similar, substantial within-cow clustering effect. There was a large withinherd clustering effect for PGR Staph. aureus and Strep. uberis, but not for CNS. Some of the findings with regard to seasonal and lactation associations were highly unexpected, particularly the seasonal association with regard to PGR. In Norway and other locations with similar conditions, this survey will result in much more attention paid to mastitis control for Staph. aureus at calving and for Strep. dysgalactiae throughout lactation. Much more focus will be placed on preventive measures during the late indoor season for Streptococcus spp. and CNS and at the start of the pasture season for Staph. aureus and Strep. uberis. Future research should test the feed quality hypothesis, especially with regard to vitamin $\mathrm{E}$ and immune system effects during the late indoor season, as well as the reason for the association between pasturing and increased numbers of isolates of Strep. uberis. Thus, the present study demonstrates the importance of a random survey as a baseline for national strategic planning of mastitis control, as many of these findings could not have been discovered from routine sampling. Such sampling would likely have included selection biases. Such surveys should be repeated regularly, as in Finland where Pitkälä et al. (2004) illustrated a large change in bacteria occurrence over $10 \mathrm{yr}$. It is most probable that different prevalences of Staph. aureus, Strep. uberis, and CNS over time and between countries requires different mastitis control programs that can be adapted to the most frequent bacteria species.

\section{ACKNOWLEDGMENTS}

The study was supported by a grant from the Research Council of Norway. Great thanks are extended to all of the advisors in TINE Norwegian Dairies for taking all of the milk samples. Access to production and health data was given by the NDHRS and the Norwegian Cattle Health Services in agreement number 1 in 2002. We thank Paul Kretchmer of San Francisco Edit for his assistance in the initial editing of this manuscript.

\section{REFERENCES}

Aarestrup, F. M., H. C. Wegener, N. E. Jensen, O. Jonsson, V. Myllys, B. M. Thorberg, S. Waage, and V. T. Rosdahl. 1997. A study of phage- and ribotype patterns of Staphylococcus aureus isolated from bovine mastitis in the Nordic countries. Acta Vet. Scand. 38:243-252.

Allison, R. D., and R. L. Laven. 2000. Effect of vitamin E supplementation on the health and fertility of dairy cows: A review. Vet. Rec. 147:703-708.

Barkema, H. W., Y. H. Schukken, T. J. G. M. Lam, D. T. Gallagan, M. L. Beiboer, and A. Brand. 1997. Estimation of interdependence among quarters of the bovine udder with subclinical mastitis and implications for analysis. J. Dairy Sci. 80:1592-1599.

Busato, A., P. Trachsel, M. Schallibaum, and J. W. Blum. 2000. Udder health and risk factors for subclinical mastitis in organic dairy farms in Switzerland. Prev. Vet. Med. 44:205-220.

Carey, V., S. L. Zeger, and P. J. Diggle. 1993. Modelling multivariate binary data with alternating logistic regressions. Biometrika 80:517-526.

De Vliegher, S., H. W. Barkema, H. Stryhn, G. Opsomer, and A. de Kruif. 2004. Impact of early lactation somatic cell count in heifers on somatic cell counts over the first lactation. J. Dairy Sci. 87:3672-3682.

Green, M. J., L. E. Green, A. J. Bradley, P. R. Burton, Y. H. Schukken, and G. F. Medley. 2005. Prevalence and associations between bacterial isolates from dry mammary glands of dairy cows. Vet. Rec. 156:71-77.

Haveri, M., S. Taponen, S. Salmenlinna, S. Pyörälä, and J. VuopioVarkila. 2005. Bacterial genotype affects the manifestation and persistence of bovine Staphylococcus aureus intramammary infection. J. Clin. Microb. 43:959-961.

Hoberman, A., J. L. Paradise, D. P. Greenberg, E. R. Wald, D. H. Kearney, and D. K. Colborn. 2005. Penicillin susceptibility of pneumococcal isolates causing acute otitis media in children: Seasonal variation. Pediatr. Infect. Dis. J. 24:115-120.

Hogan, J. S., K. L. Smith, K. H. Hoblet, D. A. Todhunter, P. S. Schoenberger, W. D. Hueston, D. E. Pritchard, G. L. Bowman, L. E. Heider, and B. L. Brockett. 1989. Bacterial counts in bedding materials used on nine commercial dairies. J. Dairy Sci. 72:250-258

International Dairy Federation. 1981. Laboratory methods for use in mastitis work. IDF Bull. No. 132. Int. Dairy Fed., Brussels, Belgium.

International Dairy Federation. 1999. Suggested interpretation of mastitis terminology. IDF Bull No. 338/1999. Int. Dairy Fed., Brussels, Belgium.

Klastrup, O., and P. Schmidt Madsen. 1974. Nordic recommendations on mastitis diagnostics from quarter milk samples. [In Danish] Nord. Med.-Vet. 26:197-204.

Kleinbaum, D. G., L. L. Kupper, and H. Morgenstern. 1982. Epidemiologic Research. Principles and Quantitative Methods. Van Nostrand Reinhold, New York, NY.

Lam, T. J., J. H. van Vliet, Y. H. Schukken, F. J. Grommers, A. van Velden-Russcher, H. W. Barkema, and A. Brand. 1997. The effect of discontinuation of postmilking teat disinfection in low somatic 
cell count herds. II. Dynamics of intramammary infections. Vet. Q. 19:47-53.

Lopez-Benavides, M. G., J. H. Williamson, R. T. Cursons, S. J. LacyHulbert, and M. W. Woolford. 2005. Streptococcus uberis population dynamics in the New Zealand pastoral dairy farm. Pages 649-655 in Mastitis in Dairy Production. Current Knowledge and Future Solutions. H. Hogeveen, ed. Wageningen Academic Publishers, Wageningen, The Netherlands.

National Veterinary Institute. 1993. Laboratory Routines in Mastitis Diagnostics at the State Veterinary Laboratories. [In Norwegian] The Natl. Vet. Inst., Oslo, Norway.

Norwegian Cattle Health Services. 2004. Annual Report. [In Norwegian] TINE Produsentrådgivning, Ås, Norway. http://storfehelse. tine.no/dok/398_ARSRAPPORT_2003.DOC. Accessed Mar. 29, 2005.

Owens, W. E., S. P. Oliver, B. E. Gillespie, C. H. Ray, and S. C. Nickerson. 1998. Role of horn flies (Haematobia irritans) in Staphylococcus aureus-induced mastitis in dairy heifers. Am. J. Vet. Res. 59:1122-1124.

Pitkälä, A., M. Haveri, S. Pyörälä, V. Myllys, and T. HonkanenBuzalski. 2004. Bovine mastitis in Finland 2001-Prevalence, distribution of bacteria, and antimicrobial resistance. J. Dairy Sci. 87:2433-2441.

Schukken, Y. H., K. E. Leslie, and A. J. Weersink. 1992. Ontario bulk milk somatic cell count reduction program. 1. Impact on somatic cell counts and milk quality. J. Dairy Sci. 75:3352-3358.

TINE Norwegian Dairies. 2001. Annual Statistics. [In Norwegian] TINE Norwegian Dairies BA, Ås, Norway.
Valde, J. P., O. Østerås, and E. Simensen. 2005. Description of herd level criteria for good and poor udder health in Norwegian dairy cows. J. Dairy Sci. 88:86-92.

van Dorp, R. T., S. W. Martin, M. M. Shoukri, J. P. Noordhuizen, and J. C. Dekkers. 1999. An epidemiologic study of disease in 32 registered Holstein dairy herds in British Columbia. Can. J. Vet. Res. 63:185-192.

Vecht, U., H. J. Wissenlink, and P. R. Defize. 1987. Report National Mastitis Survey 1985/1986. [In Dutch]

Waage, S., J. Bjorland, D. A. Caugant, H. Oppegaard, T. Tollersrud, T. Mork, and F. M. Aarestrup. 2002. Spread of Staphylococcus aureus resistant to penicillin and tetracycline within and between dairy herds. Epidemiol. Infect. 129:193-202.

Waage, S., S. A. Ødegaard, A. Lund, S. Brattgjerd, and T. Rothe. 2001. Case-control study of risk factors for clinical mastitis in postpartum dairy heifers. J. Dairy Sci. 84:392-399.

Yancey, R. J., M. S. Sanchez, and C. W. Ford. 1991. Activity of antibiotics against Staphylococcus aureus within polymorphonuclear neutrophils. Eur. J. Clin. Microbiol. Infect. Dis. 10:107-113.

Yazdankhah, S. P., H. Sorum, and H. Oppegaard. 2000. Comparison of genes involved in penicillin resistance in staphylococci of bovine origin. Microb. Drug Resist. 6:29-36.

Zadoks, R. N., B. E. Gillespie, H. W. Barkema, O. C. Sampimon, S. P. Oliver, and H. Y. Schukken. 2003. Clinical, epidemiological and molecular characteristics of Streptococcus uberis infections in dairy herds. Epidemiol. Infect. 130:335-349.

Zadoks, R. N., R. N. Gonzalez, K. J. Boor, and Y. H. Schukken. 2004. Mastitis-causing streptococci are important contributors to bacterial counts in raw bulk tank milk. J. Food Prot. 67:26442650 . 